\title{
Research on Cultivation of Journalists in Media Convergence Environment
}

\author{
Wang Ping \\ Weinan Normal University, Weinan, Shanxi, 714000
}

Keywords: Media Convergence, News Dissemination, Personnel Training, Problem Analysis

\begin{abstract}
The rapid development of information technology has promoted the popularization of the internet. The information transmission is faster and faster and the impact of the internet on people's production and life is greater. In the field of news media, information and internet technologies have promoted the integration of news media and new media. The development of news communication ushered in a new era of media convergence. However, in this environment, the training of journalists also puts forward higher requirements. The era of media convergence needs all-round development of complex talents, which requires both high professional skills, but also a strong ability to innovate. Therefore, in the process of personnel training, it is necessary to start from all aspects to better meet the requirements of the new era. This paper mainly analyzes the problems existing in the training of journalism and communication talents in the era of media convergence and puts forward some concrete solutions.
\end{abstract}

\section{Introduction}

The so-called media convergence refers to the integration of different media forms based on social needs through the means of cooperation, mergers and acquisitions, integration and other means under the support of information networks and electronic communication technologies. The convergence content includes content integration and communication channels integration and media terminals integration. In media convergence environment, the requirements of the training of news media personnel are also getting higher and higher.

\section{The Age of Media Convergence News Media Personnel Training Objectives}

In the era of media convergence, the training objectives of journalism and communication talents mainly include the following aspects:

\subsection{Cultivate students' spirit of seeking truth}

News dissemination is a respectable sacred profession. News reports are another way to uphold justice and pursue truth [1]. Its main principle is to spread the truth and report facts [2]. As an advanced cultural producer in the era of record, journalists must have the spirit of seeking truth [3]. In the era of new media, since the vigorous development of the media makes it possible for everyone to become the publisher of news and information, in this case, the truth-seeking spirit of professional journalists is even more commendable [4]. Only by establishing the truth-seeking spirit of professional journalists can we keep the social responsibility of those give full play to it. Therefore, journalists must have a rigorous and realistic spirit and report news events as objective and true as possible. Students should be trained to be sensitive and responsive to the media and to enhance their sense of social responsibility. They should not be subject to changes in objective media and technology to give up the basic principles of journalism. They should train students' good sense of professional ethics.

\subsection{Cultivate applied talents}

The news industry is rather special, and requires newscasters to have a strong professional and cultural level and the ability to apply knowledge in order to improve the quality of news information editing and reporting. Journalism, like medicine, law, business and other majors, 
requires a high level of professional application of talents, and requires possessing strong practical ability to ensure the effectiveness of news reports. Thus, we can see that the cultivation of journalism and communication talents should pay attention to the enhancement of their practical ability. They should also optimize and adjust the personnel training methods and training modes according to the actual needs of the journalistic profession in order to improve the adaptability and vocational skills of qualified personnel.

\subsection{Focus on improving the humanistic quality of personnel}

Although journalism and communication has a strong interdisciplinary character, which relies on literature, political science and sociology, and also involves economics, law, management, philosophy and art, history and so on. No matter how many majors it involves, the relationship between news media and modern information technology is becoming more and more close in media convergence environment [5]. Its subject belongs to the first level discipline of literature in higher education, that is to say, its humanities subject does not change its attributes. The vocation is still the pursuit of truth, the maintenance of justice, and the truth spread. It has a high degree of humanism, which belongs to the political theory of natural and belongs to foster the theory of democratic life. It improves the understanding and awareness of audiences to language expression and the height of the narrative form through literature, journalism.

\section{Media Convergence Era of News Media Personnel Training Problems}

Specifically, the existing problems in the training of journalism and communication talents in the era of media convergence mainly embody the following aspects:

\subsection{The goal of personnel training does not match to media integration environment}

With the transition from elitism to popularization of higher education in our country, our country's high-level personnel training also tend to carry out technical education for a certain industry [6]. Most of them are technology-oriented. Both the philosophy of thinking and the technical methods are more accurate. Based on the technical talent, however, with the rapid development of new media, there is a lack of adaptability in the current era of journalism and communication, which is relatively vague and coherent. This concept of education leads to the lack of adaptability in school education concept and social needs. In the new media era, journalism and communication professionals need sufficient information and knowledge reserves, which are highly sensitive to news events. At present, the training methods for journalism and communication talents in colleges and universities mainly focus on the single major of journalism and communication, which does not match the needs of the media in the new media era.

\subsection{The conflict between professional education and comprehensive quality education}

Under the environment of media integration, the students' comprehensive qualities are more demanding. In addition to the professional journalism and communication skills, they also need to have rich knowledge in other fields. However, there is a conflict between the professional education of journalism and communication and comprehensive quality education in China at this stage, which can not meet the actual needs of students. For example, students majoring in journalism and communication should not only study news compilation techniques, but also enhance students 'news insights and the necessary newsworthy judgment. However, the current education system lacks immediacy in students' ability cultivation. In addition, The sub-division education method adopted by the journalism and communication major can not realize the effective interaction of several branches of journalism education. This kind of situation is very unfavorable to the cultivation of students' ability of actual editing [7]. As another example, many colleges and universities take the traditional media as the teaching focus, and there is no new media platform to provide students with a practical environment. And then tudents can not experience the integration of emerging technologies and media, so they can not respond quickly to technical development needs in the actual job. 


\subsection{Teachers team construction is backward}

The training of journalism and communication personnel is strong in practice. Correspondingly, the overall quality and professional accomplishment of the instructor are also relatively high. However, all the teachers in journalism and communication in colleges and universities of our country have a serious lack of media experience despite having a high degree of education and academic degrees. Comparing the background of journalism professional teachers in China and the United States, take Peking University in our country as an example, we can see that less than one-third of any faculty members in the School of Journalism and Communication have media experience. And in the University of Missouri, the proportion of teachers with media experience is nearly $90 \%$ [8]. The main reasons for the structural contradictions of teachers specializing in journalism in colleges and universities in our country mainly come from two aspects. One is that professional education focuses on the academic research in schools, and take highly educated and high vocational education as the main directions. It ignores the industry practice, which results in a serious disconnect between the knowledge it teaches and the actual situation in the industry. On the other hand, some senior media professionals are disadvantaged in the evaluation of their academic positions due to their relatively poor academic research. Therefore, even though they have rich practical experience, The intention is not high. ,

\section{The Strategy of Media Communication Talent Cultivation under the Background of Media Convergence}

Aiming at the existing problems in the training of journalism and communication professionals in colleges and universities, it is suggested to improve the following aspects:

\subsection{Change the concept of news professional education}

In the context of media convergence, news communication is no longer a linear transmission in the traditional mode of transmission, but a dispersive transmission of point-to-point communication. In this case, the dissemination of knowledge changes from past systems gradually to a simple accumulation of information, which results in students' lack of knowledge system to the world and reflecting on their own. Therefore, the journalism major should change its own educational philosophy. In the past, simple information accumulation changed the knowledge of the system, trained personnel according to the market demand, focused on explaining the media fusion knowledge, and nurtured a multi-skill complex talents. Of course, we must uphold the ideals of news in any event of changing the ideology of news, not only to adapt to the new media environment but also to maintain a good news dissemination environment. For example, "today's headlines", the website media that claims to be "porter of news," mainly screens and reproduces unauthorized news content in its own news client, which is later sued by a number of traditional media for infringement. It can be seen from this that although the advancement of media technologies has promoted the innovation of the forms and transmission of news media, the new media has also shown remarkable creativity. However, we should emphasize the professional ethics of journalism and communication, and safeguard social justice and news ideal.

\subsection{Optimize the news education curriculum structure system}

Under the background of media convergence, it is necessary to cultivate compound talents. So we must optimize the knowledge structure of journalism students, reform the existing curriculum system, and improve the quality of personnel training under the premise of reducing the educational cost of journalism and communication, in order to improve the students' job adaptability and professionalism. First of all, we should determine the refinement of personnel training objectives, and optimize the content of general education curriculum, enabling students to have a more comprehensive and complete knowledge system during school. Increase basic literacy education curriculum, integrate and optimize the traditional extensive curriculum structure, and improve the refinement of personnel training. Second, add modern expertise to the curriculum. In 
the environment of media convergence, the content of various specialized technologies in journalism and communication work is getting higher and higher. And higher professional education should be more practical and professional. Technical courses should be set up so as to enhance students' professional media skills. Third, cultivate students' modern and open way of thinking and carry out professional training in professional thinking. In addition to professional knowledge, they should continue to improve their professional accomplishments through the training and promotion of philosophy, theoretical knowledge and moral standards. Finally, add practical teaching content. Enhance the proportion of students in the practice of journalism and practice, and comprehensively improve the practice rate of journalism and communication students.

\subsection{Strengthen "double division" type teachers}

High-quality faculty is the foundation for training qualified personnel. Under the background of media convergence, it is necessary to strengthen the construction of "double-qualified" faculty by cultivating high-quality, cross-media and application-type compound news dissemination talents. The so-called "double teacher" requires them not only having a solid theoretical knowledge and superb teaching level, but also having rich practical experience and strong professional practice ability. Under the existing education system, the teachers with double qualifications in colleges and universities are in serious deficiencies. In actual work, teachers can be improved through the strategy of "bringing in and going out". School authority can provide more opportunities for further study to in-service teachers and encourage them to rebuild their knowledge structure through self-study, training or media internship to improve their innovative abilities. In addition, they can learn from domestic and foreign universities and other media professionals to attract high-quality. And school should also regularly invite experienced media practitioners for the school special counseling, and improve the quality of journalism and teaching professionals through the combination of industry and academia.

\section{Conclusions}

In short, the development of information technology has had a huge impact on the traditional media ecology. The emergence and development of various new media have promoted the integration of media, which results in a new trend of news dissemination. News is not only the important information for the audience, but also an important window to show the degree of national civilization. It is also an important means to maintain social stability and promote social development. Therefore, under the environment of media convergence, we should change the personnel training mode of news media, establish the compound talent training system that is compatible with the media integration environment, change the teaching concept, strengthen the construction of the teaching staff, optimize the structure of news education curriculum, and development to create better conditions.

\section{Acknowledgements}

Special Research Project of Shaanxi Provincial Department of Education in 2017: Research on Promoting Shaanxi Culture's Path to Digging and Broadcasting against the Background of "Belt and Road" (17Jk0261)

\section{References}

[1] Li Zhan, Wang Shengyun. Study on the Cultivation of Communication Professionals in Local Colleges [J]. Journalism Knowledge, 2013, (9): 64-66

[2] Tong Tian-Ce. "Value Rationality" in Journalism and Communication Education in the New Media Era [J]. News and Writings, 2014, (9): 56-59. 
[3] Song Guihua. Health-oriented: the concept of journalistic talent cultivation in the era of media convergence [J]. Journal of Linyi University, 2015 (05): 54-58.

[4] Wei Yuejiao, Zhang Xiaoyan.Media fusion era of sports news dissemination personnel training program innovation [J]. NewsResearch Guide, 2016 (04): 296-297.

[5] Gao Chang. Predicament and Breakout of Journalism Talent Cultivation in the Context of Media Convergence [J], 2016 (01): 249-250.

[6] Zhou Gaoqin, TAN Kehong.Aims Adjustment and Path Exploration of News Talents Cultivation in Local Colleges and Universities in Media Fusion Times [J]. Southeastwards communication, 2017 (01): 103-105.

[7] Press and Education Project Group, School of Journalism, Renmin University of China, Ni Ning and Cai Wen. Research on Chinese Journalism and Communication in the Age of Media Convergence: A Survey Based on 18 Domestic Journalism and Communication Colleges and Departments [J]. International Press, 2014 (4): 123-134Journalism and Writing, 2009, (8) 25-33.

[8] Fu Xiaoyan. Journalism and Journalism Reform in the United States under Media Convergence - Interview with Professor Mike McKin, Founder of Media Fusion Program at the Missouri School of Journalism [J] 28. 